\title{
Religion of the past or living heritage?
}

\section{Dissemination of knowledge on Sámi religion in museums in Northern Finland}

\author{
TIINA ÄIKÄS
}

\begin{abstract}
In recent years we have witnessed a growing contemporary use of Sámi offering places by various actors, for example tourists, the local population and contemporary pagans. Hence, sites that the heritage authorities and researchers have seen as belonging to the past have gained new relevance. Nevertheless, Sámi religion is often presented in museums in relation to history and prehistory. Sámi culture has been presented in museums and exhibitions since the nineteenth century. In pointing out that this long history of museum displays affects how Sámi culture is presented in contemporary museums, Nika Potinkara (2015:41) suggests that we can renew, comment on or question the old presentations. This article explores the representations of Sámi religion in four museums and exhibitions in Northern Finland, and will answer the following research question: How is Sámi religion presented and what kind of themes are present? Here museums are studied as arenas for the dissemination of results of knowledge production. What kind of image of Sámi religion do they share?
\end{abstract}

Keywords: Sámi religion, representation, archaeology, exhibition, museum shops.

In recent years we have witnessed a growing use of Sámi offering places by various actors, for example the local population, tourists and contemporary pagans ${ }^{1}$ (Äikäs 2015, Äikäs \& Spangen 2016). Hence, sites that the heritage authorities and researchers have seen as belonging to the past have gained new relevance. Nevertheless, Sámi religion is often presented in museums in relation to history and prehistory. This creates a picture of a static and abandoned set of beliefs instead of a worldview that still influences culture, art and individual spirituality.

Sámi culture has been presented in museums and exhibitions since the nineteenth century (see for example Silvén 2008, 2014; Potinkara 2015). Nika Potinkara (2015:41) finds that this long history of museum displays affects how Sámi culture is presented in contemporary museums and suggests that we can renew, 
comment on or question the old presentations. This article will explore the representations of Sámi religion in museums and exhibitions in Finland, and answer the following research question: How is Sámi religion represented and what kind of themes are present? The themes that are found in each museum or exhibition, will be analysed and then the museums will be examined as arenas for the dissemination of results of knowledge production. What kind of image of Sámi religion do they share? Representations are culturally and politically constructed, and are always made from a specific perspective (Nieminen \& Pantti 2009:120-121; Rönkä 2014:14). Sámi religion has been a topic of interest for researchers from different disciplines, including archaeology, folklore and religious studies (e.g. Rydving 1993; Fossum 2006; Äikäs 2015). These fields have traditionally concentrated on the study of the past, a fact that might have contributed to the perseverance of pastness in the exhibitions of Sámi religion.

I approach the image of Sami religion in three museums and one exhibition in Northern Finland by highlighting common themes that are articulated in museum exhibitions. These cases from Finland offer a good point of departure, where the findings can be compared to other Nordic countries. Apart from the exhibition spaces, symbols of Sámi religion can also be found in the museum shops so I will also present which themes are selected for commercial use. Finally, I will draw conclusions as to what kind of picture the exhibitions offer of Sámi religion.

\section{SELECTED MUSEUMS AND EXHIBITIONS}

The material for this article consists of data that I have collected by documenting items and posters presenting Sámi religion in museums and exhibitions in northern parts of Finland: Sámi museum Siida and the Nature Centre of Metsähallitus in Inari, Samiland exhibition in Levi, Arktikum in Rovaniemi, and the Museum of Northern Ostrobothnia in Oulu. These include a Sámi museum, provincial museums and an exhibition that is part of the UNESCO Observatory Cultural Village programme. The latter has been created by an individual Sámi, but it offers an interesting comparison to the official museum exhibitions as it is related to contemporary use of Sámi mythology for artistic and commercial purposes.

One room in the Museum of Northern Ostrobothnia (Pohjois-Pohjanmaan museo, PPM) houses a Lapland exhibition that was built in 1983-1984. The focus of the exhibition is not on Sámi culture per se but on the work of the local schoolteacher and ethnographer Samuli Paulaharju (1875-1944) whose collections are the basis for the exhibition. In addition to Sámi artefacts, the exhibition includes Paulaharju's study and a noaidi grave that was not part of Paulaharju's work but was excavated in 1970. When the museum was renewed at the turn of the twenty-first century, the Lapland exhibition was left more or less as it was, as a museum inside a museum. Early in 2018, eleven Quick Response codes were added as part of the exhibition. When visitors open the link behind a QR code with a smartphone, they find stories about a "firefox", a mythical fox that created northern lights with its tail. The stories depict Sámi culture and history in a way that is suitable for children. The QR codes, created in collaboration with the museum, early childhood education students and the primary teacher education programme at the University of Oulu, include tasks and supplementary material that teachers can use. In August 2019, the Lapland exhibition was dismounted and the objects more or less 
154 banished to the storerooms. The future of the exhibition has not yet been decided but its previous use is seen as outdated and not suited for presenting Sámi culture (Taanila 2019).

The Arktikum museum and science centre was opened in Rovaniemi in 1992. The regional museum of Lapland that was founded in 1975 is situated here. The central themes of the museum are the cultural history and nature of Lapland (Kotivuori 2012). Sámi religion is presented in the current main exhibition Pohjoiset keinot (Northern Ways, on display since 2003), which was partly under renovation at the time the data material was collected, hence the information relating to this exhibition is based on personal communication with the museum director Hannu Kotivuori (2018). The exhibition is divided into three regional sections: Rovaniemi, Southern Lapland and Upper Lapland, of which Upper Lapland has objects and posters relating to Sámi religion and early Christianity.

The Sámi Museum, located in Inari, Finland, established in 1959 by the Sámi Association (or Samii Litto), was opened to the public in 1962 (see Harlin \& Lehtola 2019 in this volume). It started as an open-air museum exhibiting Sámi buildings and artefacts. In 1998, a new museum building with exhibition and research spaces and other services was opened for visitors and thus was the Sámi museum Siida and Nature Centre of Metsähallitus born (Jomppanen 2000). The museum, run by Sámi professionals, aims to strengthen the well-being and identity of the Sámi community (Magnani et al. 2018:164). In Siida, Sámi religion is presented in two permanent exhibitions: the cultural section of the main exhibition and in the introductory exhibition, which provides a timeline for the history of northern culture and displays archaeological finds.

The Samiland exhibition in Levi presents the culture, history and mythology of the Sámi. Built as part of the UNESCO Observatory Cultural Village programme, it opened its doors in 2011 close to the Levi Summit and Hotel Levi Panorama. It consists of exhibitions about Sámi mythology, reindeer herding, Inari Sámi, Skolt Sámi and mountain Sámi as well as an outdoor exhibition with a 300-metre long step trail where visitors can see Sámi buildings and in wintertime reindeer. The man behind the exhibition, reindeer herder and author Ante Aikio, has also written novels about Sámi mythology. ${ }^{2}$ Hence, it is no surprise that mythology and religion are also evident in Samiland, although mainly as a separate exhibition space. The exhibition area for Sámi mythology was created in cooperation with Goranus Oy and opened in 2013. It presents topics and figures of Sámi mythology with a strong visual emphasis on the characters created by Goranus, a company whose mission is to increase people's awareness of Sámi mythology.

\section{ROCK ART AND DRUMS}

Noaidi drums (goavdásat) are evident in all the studied exhibitions in some way or other, either the authentic drums, objects used for drumming, replicas of drums or pictures of drums or their symbols. The relation between rock art and motifs on Sámi drums has been discussed by archaeologists; some scholars see that even though there is a chronological and spatial distance between them, the similarity of motifs on rock art and Sámi drums points to a cultural continuation of ritual tradition (see for example Luho 1971, Núñez 1995, Lahelma 2008, Joy 2017). Despite the vast time difference between Stone Age rock art (in Finland, the rock art has been dated to approx. 5000-1500 BC using shore displacement chronology, 


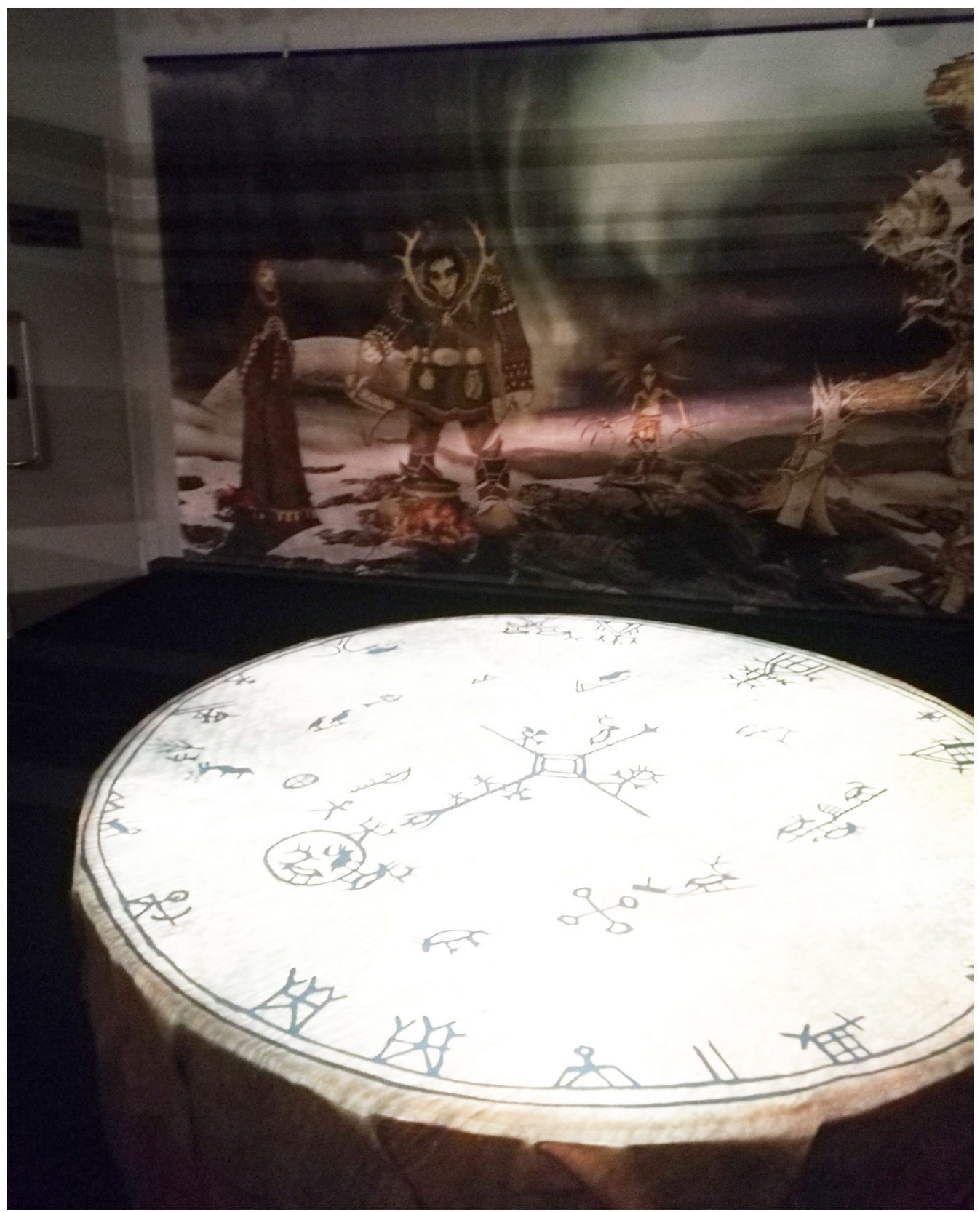

Fig. 1. A larger-than-life-size drum and mythological figures in the Samiland exhibition in Levi. Photo Tiina Äikäs, 2017. 
156 Lahelma 2008) and historical Sámi drums, pictures of rock art are displayed in exhibitions of Sámi religion, sometimes without any additional information on how they relate to Sámi religion. When a connection to rock art is made in an exhibition, it gives visitors an impression of a long tradition of Sámi religion. For example, in Samiland, a photo of Alta rock carvings is included in a poster of Sámi mythology without further explanation. Alta is a UNESCO World Heritage site along the Alta fjord, in Norway, with vast rock art panels that have thousands of carvings of humans, reindeer, fish, birds, boats and so on (Helskog 2014). These well-known figures offer a significant mental reference point for the prehistory of Sámi religion.

The connection between drums and rock art is also evident in PPM, where the text related to the QR code 8 (QR-koodi 8: Samaani ja saamelaiset uskomukset 2017) states that "old rock paintings, sacred places and drum figures tell us about the Sámi worldview" (translation by the author). Here the connection between rock art and the Sámi worldview is directly stated.

Noaidi drums, one of the most well-known elements of Sámi religion, have long been objects of interest amongst museum collectors; they have been collected since the seventeenth and eighteenth centuries when their value as a collector's item grew because they were seen as instruments related to superstition (see Silvén 2012, Nordin \& Ojala 2018). Today symbols found on the drums are used as decorations on souvenirs, jewellery, home textiles and so on. In the exhibitions, drums are often situated in a prominent place, and when no drums are actually available, there are pictures of drums and of their motifs and replicas. In Samiland, for example, there is a larger-than-life-size drum (fig. 1). In Arktikum, the so-called Yoik room, temporarily closed at the moment, has contained a picture of a drum from Utsjoki, an authentic drum hammer, indicator rings used for drumming and pieces of bone (Kotivuori personal communication 2018). The posters relating to the noaidi burial ground in PPM show a picture of a noaidi with his drum and a photo and drawing of the hammer that was found in the burial ground.

In Siida, the use of drums is presented in a separate case with figures, text, a chart of different drum types and a drum. In a press interview, the curator of the museum at the time, Arja Jomppanen, was asked about the ethical presentation of a drum in a museum exhibition. She saw no ethical problems in the display of sacred objects that had already been removed from their context in the seventeenth century. Nevertheless, the special nature of the object is taken into consideration through the way it is exhibited: it is presented in a neutral way without staging and installation (Keräilijät pelastivat saamelais-rummun polttamiselta 2013). Here it seems that the museum authorities have seen the staging of a ritual scene as disrespectful. The idea appears to be that a museum exhibit that is distanced from the past and somehow sterilised is more respectful than one that enlivens the interpretation of the past.

Drums have also proved suitable for interactive museum exhibitions. Samiland has a touch screen where visitors can obtain more information about the figures by pressing the corresponding symbol. In PPM, rock art, drums and sacred places are mentioned in the story of the firefox, QR code 8 (QR-koodi 8: Samaani ja saamelaiset uskomukset 2017). As an interactive element, children are encouraged to use some part of their own body (e.g. arm, leg, stomach) as a drum and test what kind of rhythms they can create, and to drum together. 
As the popularity of drums in museum displays is evident, it is hardly surprising that symbols from drums are also to be found in the museum shops. The Siida museum shop has postcards of the artwork "Poika" (a boy) by Merja Aletta Ranttila that depicts a little Sámi boy with a noaidi drum. Stein R. Mathisen (2015:192) describes the boy's expression as one of peaceful harmony. He makes a distinction between the idyllic depiction of noaidi practices in the artwork and the violent history of witch trials. A postcard by Irene Kangasniemi, portraying Aikia Aikianpoika (1591-1671) with his drum, depicts this other side of noaidi history. Aikia was a noaidi who was sentenced to death by the authorities at the Kemi public assembly (Fi. käräjät) allegedly for using spells to kill a peasant who had not paid him the fee he promised when Aikia had helped him with magic to have luck catching salmon. Aikia said that he had made the man fall down from a salmon weir and drown by using a drum and singing (Mäntylä 1997).

Despite the dark history of destroying drums and condemning people for using them, today the drums have acquired more positive connotations. They are used in artistic performances (Mathisen 2015) as well as in contemporary shamanistic practices where drumming courses are organised, for nonSámi people as well (Äikäs et al. 2018). The symbols on drums have frequently been used for commercial purposes (Silvén 2012), which has fuelled a discussion on the cultural appropriation of Sámi cultural elements (Mathisen 2015:205). In the Siida museum shop, the wide collection of artefacts made by local artisans includes rings and pendants that are decorated with symbols from noaidi drums. This is an example of the commercial use of the drums, also in a Sámi context. The commercial use of Sámi motifs is part of the
Sámi handicraft (duodji) tradition (Magga 2018) and hence the use of drum motifs could be seen in relation to the commercial use of other symbols.

\section{SACRED PLACES, OFFERINGS AND TREASURES}

Exhibiting sacred places and burial remains in museums raises ethical questions concerning repatriation and the sharing of sacred and secret knowledge (see for example Ladd 2001; Gabriel \& Dahl 2008; Silvén 2012). Instead of real sieidi stones, contemporary museums often exhibit photos of sieiddit taken in situ, replicas or authentic archaeological objects, such as offerings from excavations at sieddit. The collections of Nordiska Museet in Stockholm, for example, have nearly 40 sieiddit but only one is on display (Silvén 2012). Photos of sacred places are displayed in Samiland, Siida and Arktikum. There are altogether eight photos of sacred places, mainly sieiddit but also a sacred sáiva lake and a sacred island. Only the sieidi of Taatsi, Kittilä is present in more than one museum, in Samiland and in Arktikum. In Arktikum, there is also a picture from Johannes Schefferus' book Lapponia (1673) where a man is kneeling in front of an offering site (fig. 2). In addition, there is a replica of a sacred spring in the Inari Sámi section of Samiland and replicas of carved wooden poles in the outdoor section. Originally, similar wooden poles could have worked as sieiddit or as fishing statues.

Arktikum also has a photo of a stone circle from Urroaivi in Utsjoki where altogether eighteen stone circles were found in 2004 . Archaeologist Taisto Karjalainen (2007) has suggested that one possible explanation for the stone circles is that they served as an offering place. He refers to the earlier interpretations of stone circles by Ørnulv Vorren and Hans 
158 Kristian Eriksen (1993) as equivalents from Norway. In more recent research, archaeologist Marte Spangen (2016) has suggested that the stone circles in Norway are rather wolf traps than offering places. However, this research was not available when the exhibition was built.

In Siida, two silver finds have gained a prominent place in the introductory exhibition. The late Iron Age silver treasure of Nanguniemi, found in 2003 by the local writer Seppo Saraspää, and the silver head ornament found at the sacred Ukonsaari island in 1873, are displayed in separate glass cases. The silver treasure consists of four neck rings made of braided silver wires. They were placed on a birch bark plate inside a small cave. The birch bark was dated to 1160-1280 AD. The silver treasure is not interpreted as an offering but as a cache of a local or a passer-by (Ojanlatva 2003, cf. Spangen 2009). Caches and treasures are often given ritual associations by the public so perhaps the offering place interpretation is raised, and disproved, in the poster text: "Nothing at the place where the cache was found points to its use as an offering place" (translation by the author). One of the displayed silver finds, the head ornament from Ukonsaari, is, however, most likely related to the offering tradition connected to the island. The late Iron Age filigree decoration dates the silver head ornament to the latter half of the thirteenth century. The dating is somewhat earlier than the bone finds, which were excavated in 2006 and are evidence of ritual activity on the island from the fourteenth to the early seventeenth centuries (Okkonen 2007). When the head ornament was found in 1873 by the young Arthur Evans, it ended up in the Ashmolean Museum in Oxford but has been on loan at Siida since 2000 (Carpelan 2003:89; Guttorm personal communication 2019).

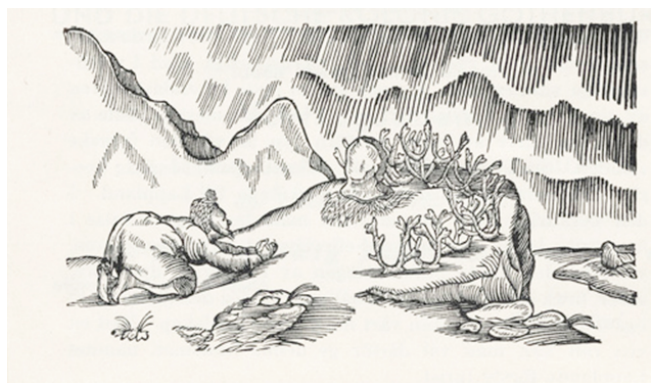

Fig. 2. A man is kneeling in front of an offering place from Johannes Schefferus' book Lapponia (1673). (c) 2019 Tromsø Museum, UiT / CC BY-NC-ND 3.0.

In September 2018, on the 15th anniversary of the finding of the Nanguniemi treasure, Siida organised a small public seminar and a host of products based on the find were made to be sold in the museum shop (Nanguniemen kätkön löytymisestä 15 vuotta, 2018). The products include beanies, shirts, necklaces, earrings, reflectors and postcards with the decorative elements from the find (fig. 3). The idea to productize this find came from the local entrepreneur and the museum, both seeing the find and its placement in the local museum as important for the people in Inari.

Sacred places are presented in the Siida main exhibition in a glass case with text, photos of sacred places, a wooden sieidi and a bear skull depicting an offering. The original location of the sieidi, a carved wooden pole, is unknown. It has been in the museum collections since the early 1960s (Guttorm personal communication 2019). A carved wooden pole is also exhibited in Arktikum where the text related to this 'fishing statue' describes the beliefs related to fishing. These wooden poles, described as keripää, fishing statues, fishing gods or fishing sieidi are mainly connected to the Sámi offering tradition, but in some cases also to more southern agricultural groups (Kotivuori 2003). 


\section{Burials}

In addition to offerings and sacred places, the display of human remains, especially of indigenous origin, also call for ethical considerations. From the early nineteenth century to the early twentieth century, human remains were collected on a wide scale and in the colonial worldview of that time, indigenous human remains were seen on a par with the flora and fauna that were collected (Fforde \& Hubert 2006:83). Later, since the 1980s, voices have been raised for the repatriation and reburial of indigenous human remains - also in Finland (Tymchuk 1984; Fforde \& Hubert 2006:87; Ruohonen 2012).

In Arktikum, the Mukkala burial ground is presented through associated finds: One iron cross, indicator rings used for drumming, rings, coins used as pendants and pieces of metal objects that had dangled on a drum. The Mukkala burial ground had eight graves, which dated to the first half of the seventeenth century. One of the Mukkala graves has been interpreted as belonging to a noaidi (Leppäaho 1936; Carpelan 1974; Kehusmaa 1995).
In the museums studied here, human remains are only on display in PPM, where a skeleton of a Sámi noaidi has been placed in a glass case together with the grave goods. The grave, found in Lehtoniemi in Kuusamo in 1970 , is interpreted as belonging to a noaidi burial based on its location, on an isolated island, and the grave finds, the hammer of a noaidi's drum and bronze indicator rings (Kopisto 1971; Niinimäki et al. 2010). The grave has been dated to the late sixteenth century based on a coin associated with it; the bones have not been dated. In the English exhibition texts, the man is described as having been a shaman. Separate text tables are used to inform about the use of the drum and the hammer and about the Lehtoniemi burial as an indicator of the long duration of shamanistic traditions. The text is illustrated with the figure of a noaidi hitting a drum. This figure is originally from the book "En kortt Relation om Lapparnes Lefwarne och Sedher, wijdskiepellsser, sampt i många Stycken Grofwe wildfarellsser" (1671) by the Swedish parson Samuel Rheen. Shamanism is also presented as a traditional Sámi belief system in the QR

Fig. 3. Postcards of the Nanguniemi treasure and commercial products based on it are sold in the Siida museum shop. Photos: Sámi Museum Siida.
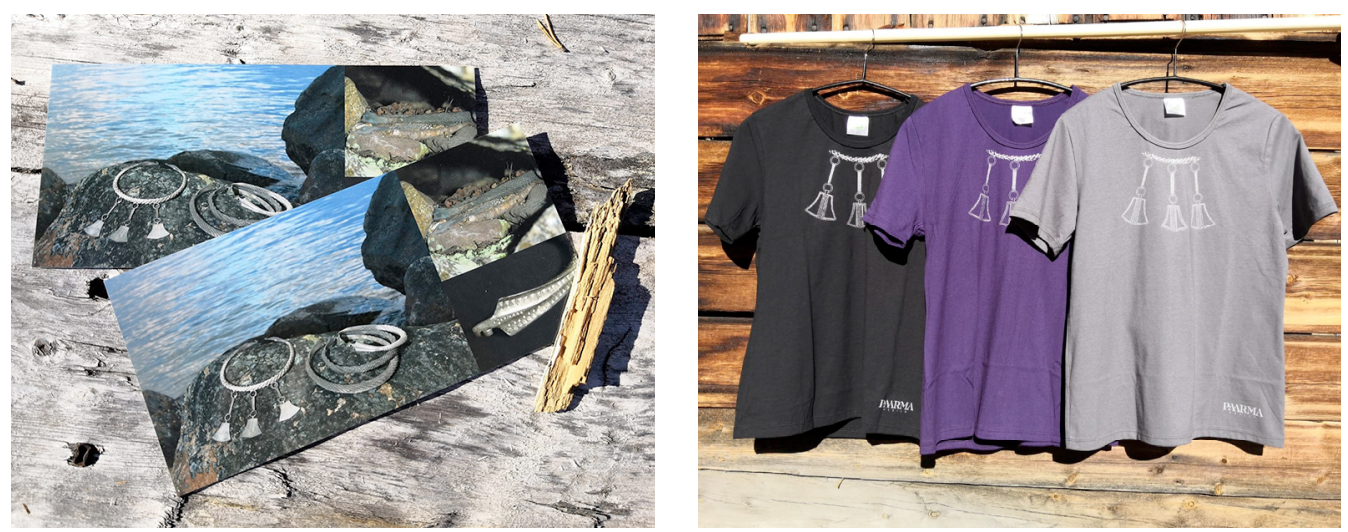


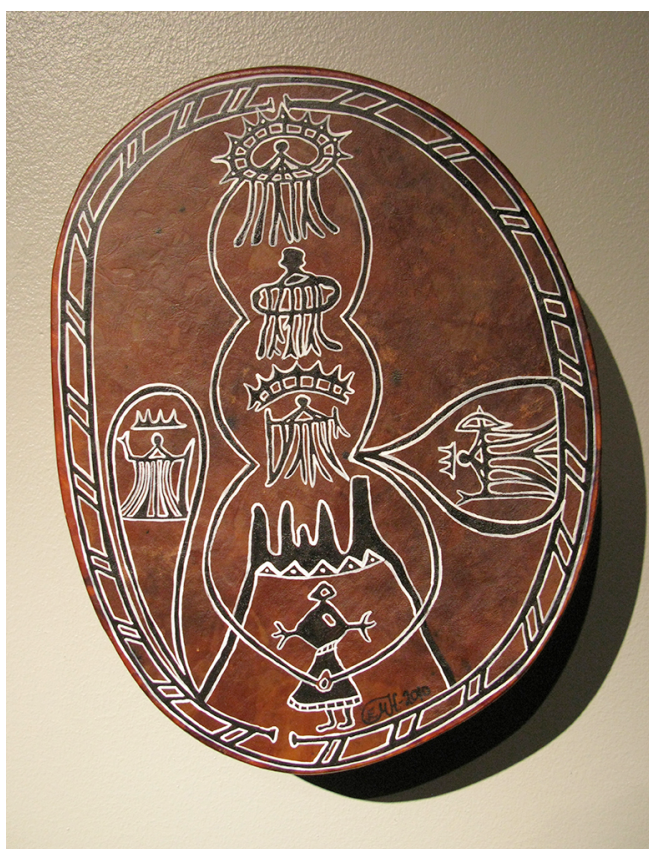

Fig. 4. Drum by Elli Maaret Helander from the "Gaovdásiid Eadni" (Mother of Drums) exhibition at Siida in the summer of 2010. Photo Tiina Äikäs, 2010.

code 8 that is related to the burial (QR-koodi 8: Samaani ja saamelaiset uskomukset 2017).

According to museum lecturer Arja Keskitalo (personal communication 2018), while there has been some debate about the display of the skeletal remains in the museum exhibition, during her time serving as a guide over the last 15 years, only one visitor has been critical. In the abstract for the Kansanuskon päivä 2018 (Day of folk religion), Professor Emeritus Juha Pentikäinen asks whether it is time to return the remains and all the grave's contents to the place of the murder. He is referring to the old interpretation that the noaidi was shot. Bullet holes are still mentioned in the exhibition posters, but they have later been proved to be the result of a post-mortem taphonomic process on the bone (Niinimäki et al. 2010). The displaying and studying of human remains has been the focus of a quite involved academic discussion (Ubelaker \& Guttenplan Grant 1989; Klesert \& Powell 1993; Jenkins 2008; Jenkins 2010; Svestad 2013) but it is interesting to note that this case has not led to debates among museum visitors. It should also be noted that in some cases, the reluctance to display human remains may be more of an academic concern than a reflection of the wishes of the locals (see e.g. Overholtzer \& Argueta 2018). However, the display of the Lehtoniemi noaidi was discussed in connection with the dismantling of the Lapland exhibition. On this occasion, archaeologist Eeva-Kristiina Harlin commented in Kaleva (Finnish newspaper) that she was relieved that the skeletal remains had been removed (Taanila 2019) because the display was unethical according to modern standards.

\section{Mythology}

Mythology is usually represented in museums as text; one exception is Samiland where mythology is visualised through drawings of various mythological figures, such as the giant Stallu, Gufittar, who lives in the sacred sáivo lakes, and the water draug, the ghost of a drowned person. These approximately life-size figures are a key feature in the exhibition space. They are drawn in a style that is familiar to the public from contemporary cartoons and hence it brings mythology into the present. In the Samiland shop, the theme from the mythology section of the exhibition is clearly continued. Visitors can buy books by Ante Aikio or T-shirts and a booklet of Sámi mythology decorated with the characters and figures that appear in both the books and the exhibition. 
In PPM, the stories of the firefox also inform us about mythology. QR code 4 (QR-koodi 4: revontulien taikaa, 2017) both tells a number of stories and provides the scientific explanation for the aurora borealis. Teachers using the material are encouraged to use a 'fire' and led lights as a prop at this stop so that children can imagine sitting by the fire and discuss their experiences of the aurora borealis. In the ceiling of the exhibition room the textile hangings resembling the aurora borealis are a key element in creating the atmosphere of the room.

\section{Christianization}

The turn from Sámi religion to Christianity is associated with the destruction of drums and sacred places and with noaidi trials. The poster text in Samiland paints a dramatic picture: "Age-old Sami mythology was almost completely forgotten a few centuries ago during the religious invasion of the 1600-1700s". At Arktikum, the text related to the Mukkala burials also refers to the battle between Christianity and Shamanism. Recent research has nevertheless pointed out that the turn from one religion to another was not necessarily dramatic as people could still carry on with old traditions even when practising Christianity. For example, some sacred sites were still in use in the twentieth century (Kylli 2005; Kylli 2012; Äikäs 2015). In most exhibitions, the Christian era is represented as something separate and sometimes even spatially situated in other parts of the museums. The poster connected to the Lehtoniemi grave in PPM has a reference to the overlapping of Christianity and Sámi religion. It is stated there that "shamanism lived long among the Sámi people, even if the priests in Lapland did their best to root it out" (translation by the author). In the stories of the firefox, QR code 8, the children are asked to compare similarities and differences between shamanism, Christianity and other religions.

At Arktikum, early Christianity is depicted through the archaeological research conducted at Markkina in Enontekiö. Historical sources suggest that there have been three churches in Markkina dating back to the seventeenth and eighteenth centuries (Halinen 2007 and the references therein). Archaeological excavations have been dug at the church site in Markkina and at the related marketplace in 1988, 1990, 1991, 2000 and 2001, and some of the material is displayed in Arktikum. Similarly, the earlier religion is evident in the archaeological finds from Juikenttä in Sodankylä. Used as a dwelling place between approximately 1000 B.C. and 1650 A.D., Juikenttä was excavated by archaeologists in the 1960s. Archaeologist Christian Carpelan (1974:61; 1987:71) has interpreted the unbroken and usable artefacts that were found from a bone waste layer as signs of ritual activities at this dwelling place. The fact that there was a drum hammer among these artefacts confirms this interpretation. Artefacts and bones found from a goahti [Sámi tent], have also been mentioned in poster text.

In the Siida museum's introductory exhibition, three pictures depict the movement from Sámi religion to Christianity: A drum, a baptismal figure and a statue of Queen Margareta I of Denmark (1353-1412) referring to another Margareta, the first Sámi mentioned by name in documents. The Sámi Margareta turned to many clergymen and even to the union queen to expedite the Christianization of the North (Lahtinen 2010). Interestingly, the caption text for the drum states: "The 'Holy Writ' of the old religion: the shaman drum", connecting old religion to Christianity with its holy writ, the Bible. In the timeline, beginning from the seventeenth century religion is 
162 mainly depicted by pictures of churches even though archaeological and historical evidence shows that old and new religions co-existed (Kylli 2005, Kylli 2012, Äikäs 2015). In the main exhibition, the cases also move from drums to churches. The case explaining the Russian Orthodox Church and Skolt Sámi culture mentions that the church maintained a tolerant stance on Sámi mythology which helped the Orthodox faith to become part of Skolt Sámi culture.

\section{The PAST IN THE PAST OR THE PAST IN THE PRESENT}

Linda Allen, Senior Curator at Museum Victoria and anthropologist Louise Hamby argue that a museum is both a "contested site where knowledge is negotiated and a field site where both contemporary and historical indigenous agency emerges" (2011:209, emphasis in the original). The architecture of the exhibition and the stories told highlight certain interpretations of the past.

The images of Sámi religion created in museums are mostly based on current academic research of the time the exhibitions were built. The exhibitions in question here are from three different decades and their age is noticeable in the appearance of the exhibition, but still their content and emerging themes are similar. More recent exhibitions or parts of exhibitions, such as the QR codes in PPM, aim to engage the museum visitors more. They bring Sámi religion from the past into the present through interaction and stories from the contemporary world.

One interpretation that is especially prevailing in the architecture of the main exhibition at Siida is the interconnectedness of nature and Sámi religion (see for example Äikäs et al. 2009; Helander-Renvall 2010). The entire main exhibition is built on the idea of nature and culture interacting. This can be seen in the exhibition architecture where the nature exhibition forms an outer layer that encircles the cultural exhibition (Pennanen 2000: Fig. 11). Because the see-through glass cases divide these two areas, the nature and culture exhibits interact with each other. Hence, even the exhibition cases containing objects and posters of Sámi religion are related to nature. The connection between nature and Sámi religion is also evident in PPM, where the QR code 8 points to the connection between the Sámi traditional belief system and nature. It states that: "The beliefs of the Sámi have traditionally been very closely tied to the elements of nature." In Arktikum, the relation between belief systems and nature is evident in the texts describing different beliefs related to fishing and hunting, especially when it comes to bears.

Another way to represent Sámi religion is to relegate it to history. In the cases discussed in this paper, Sámi religion is mainly represented through archaeological and ethnographic material, which distances religion to the past. The exhibition space itself can lead a visitor into a certain atmosphere. In Samiland, the exhibition space for Sámi religion is painted black and with dim lighting. The exhibitions have little discussion on the contemporary meanings and use of sacred sites or mythology. One exception is that the mythological figures depicted in Samiland are drawn in a modern fashion and thus bring mythology into contemporary time. Outside the exhibition, visitors can also acquaint themselves with these figures using a mobile application called "Sami Myths". Another example of exhibiting contemporary meanings of Sámi religion in the museums was the temporary exhibition of Sámi artist Elli Maaret Helander's modern 
drums at Siida in the summer of 2010 (Fig. 4). In another temporary exhibition at Siida, Eleven Images of Sámi Life Today (MayNovember 2018), the diversity of Sámi life is presented through photographs, videos and interviews. Here a photograph by artist Ola Røe has captured a Sámi woman, Reidun Johannessen, drumming. The title of the poster is "A modern Sámi shaman". These kinds of exhibitions demonstrate that elements of Sámi religion do not only belong to the past but gain new meanings in a contemporary world. Symbols of Sámi religion can be both representations of traditional spirituality and integrated into narratives of identity (Scheffy 2004:227).

Apart from examples of contemporary spirituality, an interaction with museum exhibits can also help to bring Sámi religion alive. In the studied cases, interactive elements are mainly included in Samiland exhibitions with the larger-than-life-size drum and the QR codes in PPM. From other museums we have examples also showing that a traditional exhibition of religion can be an interactive experience. Sacred objects can also act as a religious medium from a glass case. Scholar of religious science Steph Berns (2016) noted how people felt they could almost touch the sacred relics and prayed before them in an exhibition of relics at the British Museum. Even though in this case the relics were of Catholic origin and the prayers Christian, similar phenomena have been noted in a non-Christian context. There are several instances where museum visitors have left coins on the cup-marked stones in museum exhibitions (fig. 5). This habit might of course be more related to the tradition of leaving coins at touristic attractions, such as fountains, than a ritual activity. While this tradition might have a ritual background in offerings related to water spirits or gods, it has

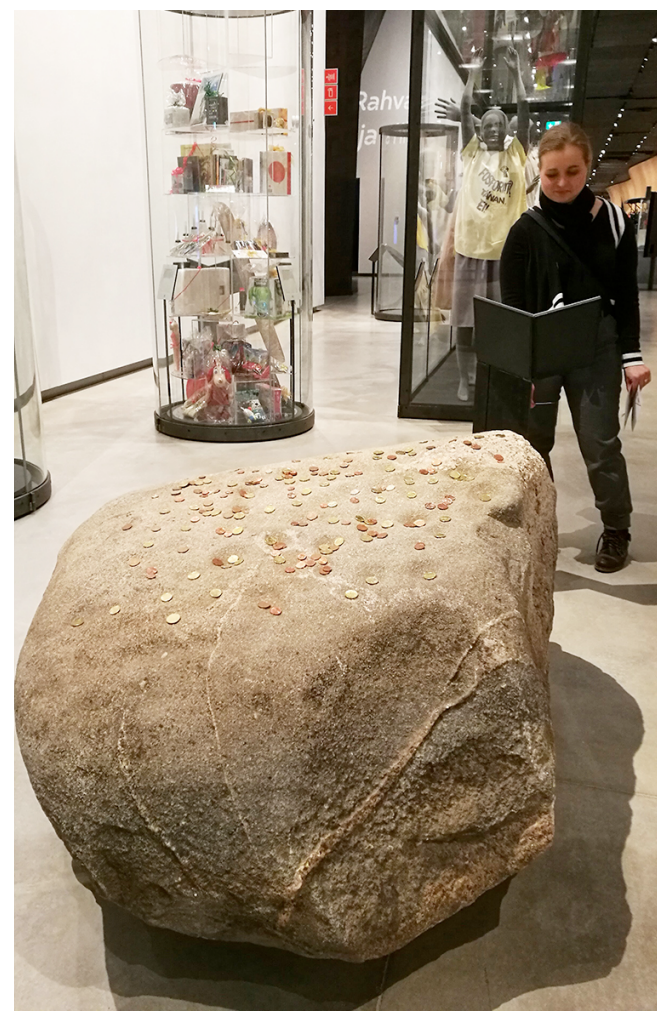

163

Fig. 5. Coins on a cup-marked stone in the Estonian National Museum mark visitors' interactions with a museum object. Photo Tiina Äikäs, 2017.

certainly become secularised. A story from Naturhistorisches Museum Wien (Natural History Museum) presents a contemporary tradition of interacting with a museum object in a ritual way: During the renovation work at the museum a curious find was discovered under the base of the female figurine Venus of Willendorf (dating between 28,000 and 25,000 $\mathrm{BCE}$ ); a bunch of yarrow (Achillea millefolium). This plant is used in alternative medicine to alleviate women's ailments, for example menstrual pains and menopausal complaints. The fact that this plant does not grow in the 
164 vicinity of the museum, its use for women's ailments and the place where the yarrow was found suggest that this was an offering made to Venus of Willendorf (Löw \& Grömer 2014). This is not the only case of deposits left at the statue. Dr. Walpurga Antl-Weiser from Naturhistorisches Museum Wien states that "the Venus of Willendorf receives small gifts from deeply devoted admirers from time to time and is almost religiously venerated" (2018:53). Whether this is done as a humoristic gesture or to mimic earlier behaviour remains unanswered, but the deposits could also be interpreted as marks of rituals.

Helena Robinson, lecturer in Museum Studies at the University of Sydney, has highlighted visitor participation and democratic access to cultural heritage as key aspects for the ongoing relevance of museums, especially for indigenous peoples (Robinson 2017). In the studied cases, visitor participation is mainly accomplished through interactive displays and additional teaching material. Buying objects with religious symbols from the museum shop can also be seen as an interaction with spiritual cultural heritage. On the other hand, it can be seen as the unwanted commercialisation of sacredness. However, archaeologist Lynn Meskell has suggested that productization, or commercialisation, does not always disconnect its object from the context of the sacred (2004:177-219). It may decrease spirituality, but may also democratize it and make its objects more accessible. Even though people do not necessarily achieve the same spiritual experience with, for example, a pendant depicting figures from a noaidi drum than with the actual drum, these products are certainly easier to get hold of and they are available to a wider audience. The object may also acquire new meanings that may or may not be related to the old spiritual meanings.

\section{Conclusion}

The examples from three museums and one exhibition in Northern Finland have demonstrated that there are shared themes in the exhibitions. Drums, sieiddit and shamans stand out as important motifs in the presentations of Sámi religion. The connection to rock art is used to refer to the prehistory of Sámi religion. This distances Sámi religion even further back in time than archaeological evidence directly suggests, whereas the contemporary meanings of Sámi religion are absent from most exhibitions. Moreover, the oft-presented contradiction between Sámi religion and Christianity creates an impression that the latter has replaced the former. This leads to a perseverance of pastness in the image of Sámi religion.

Hence when Sámi religion is exhibited in museums through the use of archaeological and ethnographic artefacts, it easily becomes relegated to the past. There are nevertheless also examples where an interplay between the past and the present takes a visible form in museums. One example of this is when museum visitors can interact with objects, in these cases replicas or props. Another example is when contemporary meanings of objects and contemporary spirituality are presented, usually in temporary exhibitions. Objects can also obtain new meanings in museum shops. Even though the productization of sacredness requires ethical considerations, it can also be a novel way of achieving spiritual engagement. Museums can display a living spiritual tradition and heritage instead of a past religion.

\section{ACKNOWLedgements}

I would like to thank Arja Keskitalo from the Museum of Northern Ostrobothnia, Hannu 
Kotivuori from Arktikum, and Anni Guttorm from Siida for their valuable comments on the exhibitions. I am also grateful to the members of the SODISAMI project for their comments on an earlier version of this article and especially Cathrine Baglo and Rossella Ragazzi for their editorial work and comments.

\section{Notes}

1. I recognise that the use of the term pagan can be problematic as it has carried negative connotations referring to a deviant not practising a main religion. The term has, nevertheless, been established in research literature and is also used as an emic category by some contemporary pagans (see e.g. Sjöblom 2000). In this study, the concept pagan is therefore understood merely as an academic notion without any qualitative implications.

2. Jänkäjärven syöverit (2013) (English translation: Fathoms of the Fenlake, 2015), Lovi (Trance) (2015), Stallun pata (Cauldron of Stallu) (2018).

\section{REFERENCES}

\section{Interviews}

Guttorm, Anni 2019. E-mail correspondence with the author on 8 January 2019.

Keskitalo, Arja 2018. E-mail correspondence with the author between 9 January and 30 October 2018.

Kotivuori, Hannu 2018. E-mail correspondence with the author on 12 December 2018.

\section{Internet sources}

Keräilijät pelastivat saamelais-rummun polttamiselta 2013. https://www.kaleva.fi/uutiset/kotimaa/ kerailijat-pelastivat-saamelais-rummunpolttamiselta/644021/ (Accessed 10 January 2019) Lahtinen, Anu 2010. "Margareta." Kansallisbiografiaverkkojulkaisu. Studia Biographica 4. Suomalaisen Kirjallisuuden Seura: Helsinki. http://urn.fi/ urn:nbn:fi:sks-kbg-009401 (Accessed 8 January

2019)

Mäntylä, Ilkka 1997. "Aikia Aikianpoika.”

Kansallisbiografia-verkkojulkaisu. Studia

Biographica 4. Suomalaisen Kirjallisuuden Seura:

Helsinki. http://urn.fi/urn:nbn:fi:sks-kbg-000338>

(Accessed 7 January 2019)

Nanguniemen kätkön löytymisestä 15 vuotta

2018. http://www.siida.fi/sisalto/tiedotteet/

nanguniemen-ktkn-lytymisest-15-vuotta

(Accessed 7 January 2019)

QR-koodi 4: Revontulien taikaa 2017. https://youtu. be/X5ZnI-MZSsU (Accessed 9 January 2019)

QR-koodi 8: Samaani ja saamelaiset uskomukset 2017. https://youtu.be/9i9ka3NtD1M (Accessed 5 December 2018)

\section{Literature}

Äikäs, Tiina 2015. From Boulders to Fells. Sacred Places in the Sámi Ritual Landscape. Helsinki: Archaeological Society of Finland.

Äikäs Tiina, Trude Fonneland, Suzie Thomas, Wesa Perttola \& Siv Ellen Kraft 2018. “"Traces of our ancient religion'. Meaning-making and shamanism at Sámi offering places and at the Isogaisa festival, northern Norway." In Jutta Leskovar \& Raimund Karl (eds.). Archaeological Sites as Space for Modern Spiritual Practice. Newcastle upon Tyne: Cambridge Scholars, 1-20.

Äikäs, Tiina, Anna-Kaisa Puputti, Milton Núñez, Jouni Aspi \& Jari Okkonen 2009. "Sacred and profane livelihood. Animal bones from sieidi sites in Northern Finland." Norwegian Archaeological Review 42:2, 109-122.

Äikäs, Tiina \& Marte Spangen 2016. "New users and changing traditions. (Re)defining Sami offering sites." European Journal of Archaeology 19:1, 95-121.

Allen, Lindy \& Louise Hamby 2011. "Pathways to knowledge. Research, agency and power relations in the context of collaborations between museums and source communities." In Sarah Byrne, Anne 


\section{TIINA ÄIKÄs}

Clarke, Rodney Harrison \& Robin Torrence (eds.). Unpacking the Collection. Networks of Material and Social Agency in the Museum. New York: Springer, 209-229.

Antl-Weiser, Walpurga 2018. “The Venus Cabinet.” In Karina Grömer \& Anton Kern (eds.). Artifacts. Treasures of the Millennia. A Guide through the Prehistoric Collection. Natural History Museum Vienna Exhibition guide. Wien: Verlag des Naturhistorischen Museums, 52-65.

Berns, Steph 2016. "Considering the glass case. Material encounters between museums, visitors and religious objects." Journal of Material Culture 21:2, 153-168.

Carpelan, Christian 1974. “Kaapit 13, 14 ja 15.” In Kemijoki 8000. Näyttelyopas: Kemijoen alueen muinaisuutta 8000 vuoden ajalta arkeologisten tutkimusten valossa. Helsinki: Museoviraston esihistorian toimisto, 57-63.

Carpelan, Christian 1987. “Juikenttä. Keskiajan ja uuden ajan alun metsäsaamelainen yhteisö arkeologisen aineiston valossa." In Raili Huopanen (ed.). Saamelaiset: Sovinnolliset sopeutujat. Oulu: Lapin maakuntamuseo, 62-76.

Carpelan, Christian 2003. "Inarilaisten arkeologiset vaiheet." In Veli-Pekka Lehtola (ed.). Inari Aanaar. Inarin historia jääkaudesta nykypäivään. Oulu: Inarin kunta, 28-95.

Fforde, Cressida \& Jane Hubert 2006. "Indigenous human remains and changing museum ideology." In Robert Layton, Stephen Shennan \& Peter Stone (eds.). A Future for Archaeology, The Past in the Present. London: UCL Press, 83-96.

Fossum, Birgitta 2006. Förfädernas land. En arkeologisk studie av rituella lämningar i Sápmi, 300 f.Kr.-1600 e.Kr. Studia Archaeologica Universitatis Umensis 22. Umeå: University of Umeå.

Gabriel, Mille \& Jens Dahl (eds.) 2008. Utimut: Past Heritage - Future Partnerships. Discussions on Repatriation in the 21st Century. Copenhagen: IWGIA/NKA.

Halinen, Petri 2007. “Enontekiön Markkinan kirkko." In Eeva-Kristiina Harlin \& Veli-Pekka Lehtola (eds.). Peurakuopista kirkkokenttiin. Saamelaisalueen 10000 vuotta arkeologin näkökulmasta. Oulu: University of Oulu, 168-177.

Harlin, Eeva-Kristiina \& Veli-Pekka Lehtola 2019. "Skolt Sámi Heritage, Toivo Immanuel Itkonen (1891-1968), and the Sámi Collections at the National Museum of Finland". Nordisk Muselogi 3, 45-60.

Helander-Renvall, Elina 2010. “Animism, personhood and the nature of reality. Sami perspectives." Polar Record 46:236, 44-56.

Helskog, Knut 2014. Communicating with the World of Beings. The World Heritage Rock Art Sites in Alta, Arctic Norway. Oxford: Oxbow Books.

Jenkins, Tiffany 2008. "Dead bodies. The changing treatment of human remains in British museum collections and the challenge to the traditional model of the museum." Mortality 13:2, 105-118. Jenkins, Tiffany 2010. Contesting Human Remains in Museum Collections. The Crisis of Cultural Authority. Routledge: New York.

Jomppanen, Tarmo 2000. “Saamelaismuseon synty ja historia." In Jukka Pennanen \& Klemetti Näkkäläjärvi (eds.). Siiddastallan - Siidoista kyliin. Luontosidonnainen saamelaiskulttuuri ja sen muuttuminen. Jyväskylä: Kustannus Pohjoinen, 19.

Joy, Francis 2017. "Noaidi drums from Sápmi, rock paintings in Finland and Sámi cultural heritage. An investigation.” Polar Record 53:2, 200-219.

Taanila, Janne 2019. "Kodan viimeiset päivät." Kaleva 25/8/2019.

Karjalainen, Taisto 2007. “Urroaivin kivikehät.” In Eeva-Kristiina Harlin \& Veli-Pekka Lehtola (eds.). Peurakuopista kirkkokenttiin. Saamelaisalueen 10000 vuotta arkeologin näkökulmasta. Oulu: University of Oulu, 146-153.

Kehusmaa, Aimo 1995. “Sodankylän, Pelkosenniemen ja Savukosken esihistoria." In Aimo Kehusmaa \& Samuli Onnela (eds.). Suur-Sodankylän historia 1. 
Jyväskylä: Suur-Sodankylän historiatoimikunta, 17-79.

Klesert, Anthony L. \& Shirley Powell 1993.

"A perspective on ethics and the reburial controversy." American Antiquity 58:2, 348-354.

Kopisto, Aarne 1971. "Kuusamon lappalaishauta." Suomen Museo 78, 64-72.

Kotivuori, Hannu 2003. "Puuhun kirjoitettu." Raito 1, 26-33.

Kotivuori, Hannu 2012. “Outamaiden ja paljakoiden kasvatit. Lapin maakuntamuseon näyttelytyö 1991-2012." In Esko Riepula (ed.). Arktikum Pohjoista valoa. Tiedekeskus ja museo Ounasjoen rannalla 20 vuotta. Rovaniemi: Lapland University Press, 46-55.

Kylli, Ritva 2005. Kirkon ja saamelaisten kohtaaminen Utsjoella ja Inarissa 1742-1886. Rovaniemi: Pohjois-Suomen Historiallinen Yhdistys.

Kylli, Ritva 2012. Saamelaisten kaksi kääntymystä. Uskonnon muuttuminen Utsjoen ja Enontekiön lapinmailla 1602-1905. Helsinki: SKS.

Ladd, Edmund J. 2001. "A Zuni perspective on repatriation." In Tamara L. Bray (ed.). The Future of the Past. Archaeologists, Native Americans, and Repatriation. New York: Garland Publishing, 107-115.

Leppäaho, Jorma 1936. "Savukosken Mukkalan lappalaiskalmisto." Kotiseutu 1936(3-4), 134-144.

Löw, Carmen \& Grömer Karina 2014. “Fundort Schausammlung. Neuzeitliche Funde beim Umbau der prähistorischen Schausäle im Naturhistorischen Museum." Archäologie Österreichs 25:2, 24-27.

Luho, Ville 1971. "Suomen kalliomaalaukset ja lappalaiset." Vanhaa ja uutta Lappia. Kalevalaseuran vuosikirja 51, 5-17.

Magga, Sigga-Marja 2018. Saamelainen käsityö yhtenäisyyden rakentajana: Duodjin normit ja brändit. Oulu: University of Oulu.

Magnani, Matthew, Anni Guttorm \& Natalia Magnani 2018. “Three-dimensional, community-based heritage management of indigenous museum collections. Archaeological ethnography, revitalization and repatriation at the Sámi Museum

Siida." Journal of Cultural Heritage 31, 162-169.

Mathisen, Stein R. 2015. "Contextualizing exhibited versions of Sami noaidevuohta." In Siv Ellen Kraft, Trude Fonneland \& James R. Lewis (eds.). Nordic Neoshamanisms. New York: Palgrave MacMillan, 191-213.

Meskell, Lynn 2004. Object Worlds in Ancient Egypt. Material Biographies Past and Present. Oxford \& New York: Bloomsbury.

Nieminen, Hannu \& Mervi Pantti 2009. Media markkinoilla. Johdatus joukkoviestintään ja sen tutkimukseen. Helsinki: Loki-Kirjat.

Niinimäki, Sirpa, Markku Niskanen, Andrew Chamberlain \& Juho-Antti Junno 2010. "Osteological analysis of a Medieval shaman burial from Kuusamo in north-eastern Finland." Fennoscandia Archaeologica XXVII, 97-100.

Nordin, Jonas M. \& Carl-Gösta Ojala 2018. "Collecting, connecting, constructing: Early modern commodification and globalization of Sámi material culture." Journal of Material Culture 23:1, 58-82.

Núñez, Milton 1995. "Reflections on Finnish rock art and ethnohistorical data." Fennoscandia archaeologica XII, 123-135.

Ojanlatva, Eija 2003. "A Late Iron Age silver deposit found at Nanguniemi, Inari, Finland." Fennoscandia archaeologica XX, 115-119.

Okkonen, Jari 2007. "Archaeological investigations at the Sámi sacrificial site of Ukonsaari in Lake Inari." Fennoscandia archaeologica XXIV, 29-38.

Overholtzer, Lisa \& Juan R. Argueta 2018. "Letting skeletons out of the closet. The ethics of displaying ancient Mexican human remains." International Journal of Heritage Studies 24:5, 508-530.

Pennanen, Jukka 2000. "Ihmisen ja luonnon vuorovaikutus saamelaiskulttuurin lähtökohtana." In Jukka Pennanen \& Klemetti Näkkäläjärvi (eds.). Siiddastallan - Siidoista kyliin. Luontosidonnainen saamelaiskulttuuri ja sen muuttuminen. Jyväskylä: Kustannus Pohjoinen, 13-18. 


\section{TIINA ÄIKÄs}

Potinkara, Nika 2015. Etnisyyden rakentuminen

kahden saamelaismuseon perusnäyttelyissä. Jyväskylä Studies in Humanities 272. Jyväskylä: University of Jyväskylä.

Robinson, Helena. 2017. "Is cultural democracy possible in a museum? Critical reflections on Indigenous engagement in the development of the exhibition Encounters. Revealing Stories of Aboriginal and Torres Strait Islander Objects from the British Museum." International Journal of Heritage Studies 23:9, 860-874.

Rönkä, Minna 2014. Ihmis- ja kulttuurikuva suomalaisissa esihistorian näyttelyissä. Unpublished master's thesis. Archaeology, University of Helsinki.

Ruohonen, Juha 2012. "Kalmistoja, kaivauksia, kallonmittausta. Fyysisen antropologian tutkimuskohteita Pohjois-Suomessa." Faravid XXXVI, 57-85.

Rydving, Håkan 1993. The End of Drum-Time. Religious Change among the Lule Saami, 1670s-1740s. Uppsala: University of Uppsala.

Schefferus, Johannes 1673. Lapponia, id est, Regionis Lapponum et gentis nova et verissima descriptio. Francofurti: Ex officina Christiani Wolffii, Typis Joannis Andreae.

Scheffy, Zoë-Hateech Durrah 2004. "Sámi religion in museums and artistry." In Anna-Leena Siikala, Barbro Klein \& Stein R. Mathisen (eds.). Creating Diversities. Folklore, Religion and the Politics of Heritage. Helsinki: SKS, 225-259.

Silvén, Eva 2008. "Staging the Sami. Narrative and display at the Nordiska Museet in Stockholm." In Andreas Nyblom \& Peter Aronsson (eds.). Comparing. National Museums, Territories, Nation-Building and Change. Linköping: Linköping University Electronic Press, 311-319.

Silvén, Eva 2012. "Contested Sami heritage. Drums and sieidis on the move." In Dominisque Poulot, José María Lanzarote Guiral \& Felicity Bodenstein (eds.). National Museums and the Negotiation of Difficult Pasts. Linköping: Linköping University Electronic Press, 173-186.
Silvén, Eva 2014. "Constructing a Sami cultural heritage. Essentialism and Emancipation." Ethnologia Scandinavica 44, 59-74.

Sjöblom, Tom 2000. "Contemporary Paganism in Finland." In Jeffrey Kaplan (ed.). Beyond the Mainstream: The Emergence of Religious Pluralism in Finland, Estonia, and Russia. Helsinki: SKS, 223-240.

Spangen, Marte 2009. "Silver hoards in Sámi areas." In Petri Halinen, Mika Lavento \& Mervi Suhonen (eds.). Recent Perspectives on Sámi Archaeology in Fennoscandia and North-West Russia. Proceedings of the First International Conference on Sámi Archaeology, Rovaniemi, 19-22 October 2006. Iskos 17, 94-106.

Spangen, Marte 2016. Circling Concepts. A Critical Archaeological Analysis of the Notion of Stone Circles as Sami Offering Sites. Stockholm: University of Stockholm.

Svestad, Asgeir 2013. "What Happened in Neiden? On the Question of Reburial Ethics." Norwegian Archaeological Review 46:2, 194-222.

Tymchuk, Michael 1984. "Skeletal remains. In defense of sensitivity and compromise." Museum Anthropology 8:3, 2-8.

Ubelaker, Douglas H. \& Lauryn Guttenplan Grant 1989. "Human skeletal remains. Preservation or reburial?” American Journal of Physical Anthropology 32:S10, 249-287.

Vorren, Ørnulv \& Hans Kr. Eriksen 1993. Samiske offerplasser $i$ Varanger. Tromsø Museums skrifter XXIV. Stonglandseidet: Nordkalott-forlaget.

Tiina Äikäs, Ph.D. tiina.aikas@oulu.fi

Archaeology, University of Oulu P.O. Box 1000 90014 University of Oulu, Finland https://www.oulu.fi/university/researcher/ tiina-aikas 